\title{
THE ROLE OF BIOLOGICAL AGENTS IN THE CONTROL OF SPIDER MITES INFESTING TOMATO PLANTS
}

\author{
M. H. Mahagoub \\ Dept. of Vegetable and Ornamental Pests, Plant Prot. Res. Institute, A.R.C. Dokki, Giza
}

Received: Feb. 13, 2017

Accepted: Apr. 23, 2017

\begin{abstract}
A semi-field experiment was carried out at Plant Protection Research Institute, Dokki, Giza under green house conditions, to evaluate the effect of the predatory mite, Phytoseuilus persimilis as a predaceous mite and the crude extract of Lantana camara (2 $\mathrm{g} /$ liter water) in addition to the acaricide, Ortus $5 \% E C$ at the rate of $2 \mathrm{ml} /$ liter water against the two spotted spider mite, Tetranychus urticae infesting tomato plants. Results indicated that the reduction percentages of the adult stages of the spider mites were 89.7, 50.2 and $76.7 \%$ in 2014 season for Phytoseuilus persimilis, the extract of Lantana camara and Ortus $5 \%$ EC, respectively, while the reduction percentages were 94.6,74.1, and $81.7 \%$ for spider mite eggs , respectively. Meanwhile, results indicated that the reduction percentages of the adult stages of the spider mites were 91.7, 48.6 and $76.3 \%$ in 2015 season for Phytoseuilus persimilis, the extract of Lantana camara and Ortus $5 \%$ EC , respectively, while the reduction percentages were 93.7,72.5, and $82.0 \%$ for spider mite eggs, respectively.
\end{abstract}

Key words: Lantana camara, Phytoseuilus persimilis, Tetranychus urticae, Vegetables

\section{INTRODUCTION}

Tomato, Solanum lycopersicum (Fam.: Solanaceae) is one of the most important vegetable crops in Egypt. It is cultivated in large tracts and it represents one third of the total vegetable area in Egypt. To protect tomato plants from cooler air and exposure to frost during winter, plants are grown under plastic tunnels. Spider mites are widespread pests attacking a wide variety of agricultural crops causing damage either directly by sucking plant sap or indirectly by transmitting plant diseases.

The integrated pest management means the use of different methods of potential agents to suppress population densities of pests. From this point of view, the present study is an attempt to evaluate the efficacy of three different control methods in suppressing spider mites attacking tomato plants under greenhouse conditions.

Many authors have studied the effect of predaceous mites on the changes in the populations of $T$. urticae such as El-Badry and Zaher, 1961; Zaher and Shehata, 1971; Port and Scopes, 1981; El-Laithy, 1992; Watanabe et al., 1994; Strong and Croft,
1995; McMurtry and Croft, 1997; Ali, 1998; Heikal and Moawfi, 1998; Heikal et al., 2000; Heikal and Ibrahim, 2001; Heikal and Fawzy, 2003; Ali et al., 2005; Hassan et al., 2007; Khalequzzman et al., 2007 and Fiedler, 2012.

Many products of botanical origin proved to have ovicidal, repellent, antifeedant and toxic activity against insects and spider mites. Many researchers have experienced these results (Muzemu et al., 2011; AbdelMoniem et al., 2012; Antonious et al., 2014; Geng et al., 2014 and Rajashekar et al., 2014).

On the other hand, the chemical control of spider mites have been used widely all over the world. Chemical have been used either to protects seeds before emergence above the ground or to protect newly emerged seedlings and later the growing plants (Price, 1993; Hossain et al., 2006; Hassan et al., 2008; Pozzebon et al., 2011 and Shah and Shukla, 2014).

The present study was conducted to evaluate the effect of different potential agents to control red spider mite infestation under greenhouse conditions. 


\section{MATERIALS AND METHODS}

This experiment was conducted at a greenhouse of the Agricultural Experimental Station belonging to the Plant Protection Research Institute at Dokki, Giza Governorate for two successive seasons (2014 and 2015). The effect of the predatory mite (Phytoseiulus persimilis Athias-Henriot), botanical extract (Lantana camara L.) and the chemical acaricide (Ortus) against the spider mite, Tetranychus urticae Koch infesting tomato plants (Alex 61 cultivar) was evaluated. Tomato seedlings (30 days old) were transplanted in small plastic pots (16 $\mathrm{cm}$ in diameter) filled with clay: peat moss (1:1), one seedling per each pot in 15 April, 2014 and 2015. Pots were inoculated with $20 T$. urticae stages, maintained under greenhouse conditions of about $30^{\circ} \mathrm{C}$. Pots were divided into four groups where four applications were conducted, the first group were used to evaluate the predatory mite, $P$. persimilis, the second group to evaluate Lantana camara extract, the third group to evaluate the acaricide, Ortus, and the last one served as a control.

\section{a) The biological control agent:}

Individuals of the predatory mite, $P$. persimilis were obtained from its mass rearing on the spider mite $T$. urticae on bean plants in the laboratory (Mahgoub, 2006). Releasing of the predatory mite was applied at a level ranged between 1:7-1:10 of $P$. persimilis : T. urticae on tomato plants. Bean leaves with the predatory mite were transferred in an ice box to the pots cultivated with tomato in the greenhouse. After releasing, samples were taken weekly and the active stages of both the predatory mite and the spider mite were counted. The reduction percentages in spider mite stages were determined using the formula of Henderson and Tilton (1955).

\section{b) The botanical extract: Preparation of the plant extract of Lantana camara:}

Healthy leaves of Lantana camara were washed to get rid of any pests or dust, dried in shady place at room temperature. After dryness, leaves were crushed and $400 \mathrm{~g}$ of the plant powder were put in a glass beaker, soaked in one liter of distilled water and left for 72 hrs., then filtered and the filtrate was left to dry. The acute dry matter was put in a sealed bottle and saved in the refrigerator until use. The extracted matter was used with the concentration of $2 \mathrm{~g} /$ liter water (Jepson et al., 1975 and Kennedy, 1986).

Sampling procedure was carried out from May $3^{\text {rd }}$ up to July $8^{\text {th }}$ during both seasons. Pre-spray counts were made to determine the initial population density of $T$. urticae. The reduction percentage in spider mite individuals was determined using the formula of Henderson and Tilton (1955).

\section{c) The chemical control agent:}

Trade name: ORTUS ${ }^{\circledR}$ 5\% SC Suspension Concentration.

Active ingredient : Fenpyroximate $5 \% \mathrm{w} / \mathrm{w}$. Description: ORTUS $\AA 5 \%$ SC is a oxime compound used as a acaricide. It inhibits the cell respiration of pest.

The acaricide, Ortus 5\% SC was used at a rate of $2 \mathrm{ml} /$ liter water. The acaricide was applied as the population density of spider mites reached average of 5.7 individuals/tomato leaf. Weekly samples of tomato leaves were randomly taken before and after spraying. The reduction percentage in eggs and motile stages of $T$. urticae was determined using the formula of Henderson and Tilton (1955).

Survey was done on May $10^{\text {th }}$ on one plant/pot for the above mentioned treatments. Samples of 12 leaves per treatment were taken randomly making a sum of 48 leaves for all treatments before spraying (pre-count) then weekly counts were done after application. Collected samples were transferred to the laboratory for examination and counting the eggs and active stages of $T$. urticae (adults and immature). 


\section{RESULTS AND DISCUSSION}

The results of testing the effect of three potential control agents viz.: a biological control agent, Phytoseiulus persimilis; a plant extract of Lantana camara and a chemical acaricide, Ortus 5\% EC against Tetranychus urticae on tomato plants (Alex 61) during two successive seasons are shown in Tables $(1 \& 3)$. The reduction percentages in the population of $T$. urticae due to the use of these three agents are shown in Tables $(2 \& 4)$.

\section{Abundance of T. urticae population during 2014 season:}

Data presented in Table (1) show that the treatments applied twice; on the day of precount of $T$. urticae population May $3^{\text {rd }}$ and on June $2^{\text {nd }}$ during 2014 season had a pronounced effect on the target pest. Counting of adults, immature and egg stages began three weeks after transplanting of tomato seedlings on 12 leaves per treatment and numbers are presented as averages of these counts/leaf. The population density of $T$. urticae in the untreated pots reached $8.3,23.5$ and 14.1 for adults, immature and egg stages, respectively.

The population of the pest was 8.3, 23.6 and 14.6, respectively in the pots of $P$. persimilis; while the different stages were 8.6, 23.2 and 14.3 individuals, respectively in the pots treated with $L$. camara leaf extract, while these numbers were 8.3, 23.5 and 14.3 individuals in the treated pots with Ortus.

After one week of the first application, the population density of $T$. urticae decreased to reach 4.2 adults, 9.3 immature stages and 6.1 eggs in the $P$. persimilis treatment. In the pots treated with the plant extract, average numbers reached $4.9, \quad 9.1$ and 7.2 individuals; while it reached 1.9, 2.1 and 3.2 individuals in the chemical pesticide treatment. On the other hand, average numbers of $T$. urticae different stages were increased in the control treatment being 12.7 adults, 48.4 immatures and 23.1 eggs/tomato leaf. The decrease in the average population density continued for two weeks more in the treatments of the plant extract and Ortus after which the population density of $\mathrm{T}$. urticae increased again. The populations of different stages in the $P$. persimilis application area were continued to decrease due to the activity of the bio-agent.

After the second application (on June 2nd), the efficiency of $P$. persimilis was increased considerably and the populations of immature stages and adults of $T$. urticae were disappeared from tomato leaves till the end of the experiment on July 8th. The population density of different stages were decreased in the pots treated with $L$. camara plant extract reaching 5.2, 10.1 and 7.8 for adults, immatures and eggs, respectively. These averages were 1.9, 2.1 and 4.1 individuals in the pots treated with Ortus. By the end of the season, the populations of $T$. urticae different stages were all increased in the different treatments - except the release of $P$. persimilis - and untreated pots. Average numbers reached 40.2, 49.2 and 42.1 for adults, immatures and eggs, respectively in the plant extract treatment. These averages were 23.1, 38.0 and 32.2, respectively in the Ortus treatment; while it were highly increased in untreated plots being, 60.2, 107.1 and 87.1 individuals, respectively.

\section{The reduction percentages in $T$. urticae population due to different treatments:}

Data presented in Table (2) show the percentages in $T$. urticae due to different treatments. It is easy to notice that there is a significant difference between the effect of using $P$. persimilis as a natural enemy for $T$. urticae than the other two control measures. The highest percentages in population reduction were in the pots treated with chemical acaricide (Ortus) being $85.0 \%$ in adult population, $96.0 \%$ in immature 
population and $86.5 \%$ in egg population; while the lowest percentages of reduction were in the pots treated with the L. camara plant extract.

Table (1): Average numbers of Tetranychus urticae stages per tomato leaf as affected by $P$. persimilis release and $L$. camara extract compared to Ortus during 2014 season

\begin{tabular}{|l|c|c|c|c|c|c|c|c|c|c|c|c|}
\hline \multirow{2}{*}{ Date } & \multicolumn{3}{|c|}{ Control } & \multicolumn{3}{c|}{ P. persimilis } & \multicolumn{3}{c|}{ Lantana extract } & \multicolumn{3}{|c|}{ Ortus 5\% EC } \\
\cline { 2 - 13 } & A & I & E & A & I & E & A & I & E & A & I & E \\
\hline $\mathbf{3 / 5 / 2 0 1 4}$ & 8.3 & 23.5 & 14.1 & 8.3 & 23.6 & 14.6 & 8.6 & 23.2 & 14.3 & 8.3 & 23.5 & 14.3 \\
\hline $\mathbf{1 0 / 5}$ & 12.7 & 48.4 & 23.1 & 4.2 & 9.3 & 6.1 & 4.9 & 9.1 & 7.2 & 1.9 & 2.1 & 3.2 \\
\hline $\mathbf{1 7 / 5}$ & 15.7 & 59.2 & 45.2 & 5.1 & 8.2 & 4.2 & 11.4 & 14.6 & 11.3 & 4.4 & 6.3 & 8.1 \\
\hline $\mathbf{2 4 / 5}$ & 22.9 & 63.4 & 56.2 & 2.4 & 4.2 & 3.2 & 19.2 & 26.1 & 16.3 & 7.2 & 18.3 & 13.5 \\
\hline $\mathbf{2 / 6}$ & 34.2 & 70.5 & 61.2 & 1.1 & 2.1 & 1.3 & 28.3 & 38.2 & 22.2 & 15.2 & 27.1 & 17.3 \\
\hline $\mathbf{9 / 6}$ & 41.2 & 75.6 & 69.2 & 0.9 & 1.5 & 0.7 & 5.2 & 10.1 & 7.8 & 1.9 & 2.1 & 4.1 \\
\hline $\mathbf{1 6 / 6}$ & 45.8 & 83.2 & 72.1 & 0.0 & 0.0 & 0.0 & 12.3 & 26.2 & 12.6 & 5.0 & 10.2 & 10.2 \\
\hline $\mathbf{2 3 / 6}$ & 52.2 & 92.5 & 79.2 & 0.0 & 0.0 & 0.0 & 20.2 & 24.2 & 20.2 & 10.3 & 18.1 & 16.5 \\
\hline $\mathbf{3 0 / 6}$ & 58.3 & 98.2 & 84.1 & 0.0 & 0.0 & 0.0 & 34.2 & 38.2 & 28.4 & 18.6 & 29.2 & 20.1 \\
\hline $\mathbf{8 / 7}$ & 60.2 & 107.1 & 87.1 & 0.0 & 0.0 & 0.0 & 40.2 & 49.2 & 42.1 & 23.1 & 38.0 & 32.2 \\
\hline Average & 59.2 & 72.2 & 35.1 & 3.0 & 4.9 & 2.2 & 18.2 & 25.9 & 18.5 & 13.9 & 17.5 & 9.6 \\
\hline
\end{tabular}

$\mathrm{A}=$ Adults $\quad \mathrm{I}=$ Immature stages $\quad \mathrm{E}=$ Eggs

${ }^{*}=$ The date of the second application of different treatments

Table (2): Reduction percentages in Tetranychus urticae stages on tomato leaves after 10 weeks of application with Phytoseiulus persimilis and L. camara extract and Ortus 5\%

\begin{tabular}{|l|c|c|c|c|c|c|c|c|c|}
\hline \multirow{2}{*}{ Date } & \multicolumn{3}{|c|}{ P. persimilis } & \multicolumn{3}{c|}{ Lantana extract } & \multicolumn{3}{c|}{ Ortus 5\% EC } \\
\cline { 2 - 11 } & A & I & E & A & I & E & A & I & E \\
\hline $10 / 5 / 2014$ & 66.4 & 81.0 & 74.3 & 62.8 & 80.9 & 69.1 & 85.0 & 95.7 & 86.5 \\
\hline $17 / 5$ & 67.1 & 86.2 & 91.0 & 30.6 & 75.1 & 75.4 & 72.6 & 89.4 & 82.3 \\
\hline $24 / 5$ & 89.7 & 93.4 & 94.6 & 19.5 & 58.3 & 71.4 & 68.2 & 71.3 & 76.3 \\
\hline $2 / 6^{*}$ & 96.8 & 97.0 & 98.0 & 20.5 & 45.2 & 64.2 & 55.2 & 61.6 & 72.1 \\
\hline $9 / 6$ & 97.9 & 98.0 & 99.0 & 87.9 & 89.5 & 88.8 & 95.4 & 97.3 & 94.1 \\
\hline $16 / 6$ & 100.0 & 100.0 & 100.0 & 74.1 & 68.1 & 82.7 & 89.0 & 87.7 & 86.1 \\
\hline $23 / 6$ & 100.0 & 100.0 & 100.0 & 62.8 & 62.6 & 74.8 & 80.2 & 80.5 & 79.4 \\
\hline $30 / 6$ & 100.0 & 100.0 & 100.0 & 43.6 & 60.6 & 66.6 & 68.0 & 70.3 & 76.5 \\
\hline Average & 89.7 & 94.5 & 94.6 & 50.2 & 67.5 & 74.1 & 76.7 & 81.7 & 81.7 \\
\hline
\end{tabular}


The relevant percentages of reduction were $62.8 \%$ in adults, $80.9 \%$ in immatures and $69.1 \%$ in eggs. The release of $P$. persimilis to control the population of $T$. urticae led to reduction percentages reached $66.4 \%$ in adults, $81.0 \%$ in immatures and $74.3 \%$ in eggs. After three more weeks, the release of $P$. persimilis proved to be the most effective method in controlling $T$. urticae population than other treatments. Reduction percentages were 96.8, 97.0 and $98.0 \%$ in adult, immature and egg populations, respectively. On the other hand, the lowest reduction percentages were in plant extract treatment being 20.5, 45.2 and $64.2 \%$ in adult, immature and egg populations, respectively.

The reduction percentages in population of the spider mite were much higher than those obtained by the plant extract, the reduction percentages were $55.2 \%$ in adults, $61.6 \%$ in immature and $72.1 \%$ in eggs.

\section{Abundance of $T$. urticae population during 2015 season:}

Data presented in Table (3) show that the applied treatments also had a great effect on the population of different stages of $\mathrm{T}$. urticae. While the different stages had increased in the untreated treatment, these stages were drastically decreased in all treatments after one week of treatment (i.e. on May 10th). Average numbers reached 4.4 adults, 10.7 immatures and 7.4 eggs, respectively in the bio-agent ( $P$. persimilis) application. The same trend was observed for the other two treatments (L. camara extract and the acaricide, Ortus). After this decrease, the population began to increase steadily till the second spraying was applied especially in the plant extract and acaricide treatment. Again, three weeks after of the application of the second spray, the population of $T$. urticae different stages reached none at the pots where $\mathrm{P}$. persimilis was released. The average numbers reached 22.4, 35.2 and 21.3 for adults, immatures and egg stages, respectively.
These averages were much lower 9.4, 19.0 and 14.6 individuals, respectively while a huge increase occurred in untreated pots till the end of the experiment.

The reduction percentages in $T$. urticae population due to different treatments:

Data presented in Table (4) show the percentages in $T$. urticae due to different treatments during 2015 season. Again, it is easy to notice the significant differences between the effect of the chemical acaricide (Ortus) and either the plant extract or the bio-agent $P$. persimilis one week after the first spray. The reduction percentages reached $88.2,93.8$ and $82.3 \%$ in adults, immatures and egg populations, respectively. By the time of the second spray (June $2^{\text {nd }}$ ), the reduction percentages due to the release of $P$. persimilis were much higher than those of the plant extract or Ortus. The averages reached $97.2 \%$ for adults, $96.2 \%$ for immatures and $97.5 \%$ for eggs. These percentages were $28.5,47.7$ and $62.2 \%$ for the stages, respectively in the case of the plant extract. The high reduction percentages in $T$. urticae population were increased till the end in pots where $P$. persimilis was released. These percentages were much lower in the other treatments especially where the plant extract was used. From the previously obtained, it is wellnoticed that the use $P$. persimilis was very effective in reducing $T$. urticae populations on tomato plants.

These results are in agreement with those obtained by Ali et al. (2005) who found that $P$. macropilis is had a short life cycle when fed on T. urticae. Hassan et al. (2007) reported that using $P$. macropilis and spraying Ortus against $T$. urticae gave good results of control at plastic houses in Nubaria. El-Laithy et al. (2008) found that the reduction percentages of different stages of $T$. urticae was achieved after releasing $P$. persimilis at prey-predator ratio $1: 10$ and $1: 7$ ranged between $50-80 \%$ in Behera 
Governorate. Mahgoub et al. (2011) reported that releasing $P$. persimilis and Neoseiulus californicus on pepper cultivars to control $T$. urticae population gave very high reduction percentages in all stages. Similar results were also obtained by Watanabe et al., 1994; Strong and Croft, 1995; McMurtry and Croft, 1997; Ali, 1998; Heikal and Moawfi, 1998; Heikal et al., 2000; Heikal and Ibrahim, 2001; Heikal and Fawzy, 2003; Ali et al., 2005; Hossain et al., 2006; Hassan et al., 2007; Khalequzzman et al.,
2007; Pozzebon et al., 2011; Fiedler, 2012; Abdel-Moniem et al., 2012; Antonious et al., 2014; Geng et al., 2014 and Shah and Shukla, 2014.

It could be concluded that, it is not recommended to use either or plant extract as well as the chemical acaricide alone to control $T$. urticae in tomato fields, it is suggested that an IPM strategy based on chemical and biological agents should be applied.

Table (3): Average numbers of $T$. urticae stages / tomato leaf as affected by the release of $P$. persimilis and treatment with $L$. camara extract and Ortus during 2015 season

\begin{tabular}{|l|c|c|c|c|c|c|c|c|c|c|c|c|}
\hline \multirow{2}{*}{ Date } & \multicolumn{3}{|c|}{ Control } & \multicolumn{3}{c|}{$\boldsymbol{P}$. persimilis } & \multicolumn{3}{c|}{ Lantana extract } & \multicolumn{3}{c|}{ Ortus 5\% EC } \\
\cline { 2 - 15 } & A & I & E & A & I & E & A & I & E & A & I & E \\
\hline $\mathbf{3 / 5 / 2 0 1 5}$ & 10.4 & 25.2 & 19.1 & 10.4 & 28.2 & 18.6 & 9.9 & 27.6 & 19.0 & 10.2 & 27.0 & 19.2 \\
\hline $\mathbf{1 0 / 5}$ & 13.5 & 46.5 & 25.3 & 4.4 & 10.7 & 7.4 & 4.5 & 9.5 & 8.9 & 1.6 & 3.1 & 4.5 \\
\hline $\mathbf{1 7 / 5}$ & 21.6 & 60.2 & 50.2 & 3.3 & 7.4 & 5.2 & 9.3 & 15.4 & 13.5 & 4.5 & 7.6 & 9.1 \\
\hline $\mathbf{2 4 / 5}$ & 24.7 & 66.4 & 58.2 & 2.7 & 4.6 & 3.1 & 18.2 & 27.5 & 18.6 & 9.5 & 20.1 & 15.4 \\
\hline $\mathbf{2 / 6 ^ { * }}$ & 35.9 & 72.2 & 67.2 & 1.0 & 3.1 & 1.6 & 24.4 & 40.5 & 25.2 & 18.4 & 25.4 & 19.6 \\
\hline $\mathbf{9 / 6}$ & 40.6 & 78.9 & 73.3 & 0.9 & 2.1 & 1.1 & 13.2 & 9.2 & 8.2 & 2.1 & 3.1 & 3.2 \\
\hline $\mathbf{1 6 / 6}$ & 48.2 & 85.2 & 78.2 & 0.1 & 1.1 & 0.2 & 19.4 & 24.9 & 13.6 & 5.2 & 10.5 & 7.3 \\
\hline $\mathbf{2 3 / 6}$ & 53.1 & 93.1 & 84.3 & 0.0 & 0.8 & 0.0 & 22.4 & 35.2 & 21.3 & 9.4 & 19.0 & 14.6 \\
\hline $\mathbf{3 0 / 6}$ & 61.1 & 98.7 & 90.2 & 0.0 & 0.0 & 0.0 & 31.5 & 39.7 & 30.1 & 15.2 & 31.1 & 20.1 \\
\hline $\mathbf{8 / 7}$ & 68.2 & 100.3 & 98.2 & 0.0 & 0.0 & 0.0 & 39.2 & 50.2 & 45.1 & 21.7 & 49.6 & 25.6 \\
\hline Average & 64.4 & 72.7 & 38.1 & 3.7 & 5.8 & 2.3 & 20.4 & 28.0 & 19.2 & 13.9 & 19.7 & 9.8 \\
\hline
\end{tabular}

Table (4): Reduction percentages in T. urticae stages on tomato leaves after 10 weeks of application with Phytoseiulus persimilis and L. camara extract and Ortus $5 \%$

\begin{tabular}{|l|c|c|c|c|c|c|c|c|c|}
\hline \multirow{2}{*}{ Date } & \multicolumn{3}{|c|}{ P. persimilis } & \multicolumn{3}{c|}{ Lantana extract } & \multicolumn{3}{c|}{ Ortus 5\% EC } \\
\cline { 2 - 10 } & A & I & E & A & I & E & A & I & E \\
\hline $\mathbf{1 0 / 5 / 2 0 1 5}$ & 67.7 & 79.5 & 70.1 & 65.2 & 81.3 & 64.6 & 88.2 & 93.8 & 82.3 \\
\hline $\mathbf{1 7 / 5}$ & 81.4 & 89.0 & 89.3 & 44.5 & 76.6 & 73.0 & 73.8 & 88.2 & 82.0 \\
\hline $\mathbf{2 4 / 5}$ & 89.2 & 93.8 & 94.4 & 22.6 & 62.1 & 67.9 & 60.6 & 71.7 & 73.6 \\
\hline $\mathbf{2 / 6}{ }^{*}$ & 97.2 & 96.2 & 97.5 & 28.5 & 48.7 & 62.2 & 47.5 & 67.2 & 71.0 \\
\hline $\mathbf{9 / 6}$ & 98.0 & 97.7 & 98.5 & 68.8 & 89.3 & 88.7 & 95.1 & 96.3 & 95.6 \\
\hline $\mathbf{1 6 / 6}$ & 99.9 & 98.8 & 99.8 & 57.8 & 73.3 & 82.5 & 88.9 & 88.5 & 90.7 \\
\hline $\mathbf{2 3 / 6}$ & 100.0 & 99.2 & 100.0 & 55.7 & 65.5 & 74.6 & 81.6 & 81.0 & 82.8 \\
\hline $\mathbf{3 0 / 6}$ & 100.0 & 100.0 & 100.0 & 45.9 & 63.2 & 66.4 & 74.5 & 70.6 & 77.8 \\
\hline Average & 91.7 & 94.3 & 93.7 & 48.6 & 70.0 & 72.5 & 76.3 & 82.2 & 82.0 \\
\hline
\end{tabular}


Table (5): Mean numbers of the predatory mite, Phytoseiulus persimilis / leaf after releasing on tomato plants during 2014 and 2015 seasons.

\begin{tabular}{|l|c|c|}
\hline \multirow{2}{*}{ Date of examination } & \multicolumn{2}{c|}{ Mean numbers of the predatory mite, $\boldsymbol{P}$. persimilis / leaf } \\
\cline { 2 - 3 } & $\mathbf{2 0 1 4}$ & $\mathbf{2 0 1 5}$ \\
\hline $\mathbf{1 0}$ May & 3.7 & 4.6 \\
\hline $\mathbf{1 7}$ & 5.1 & 5.8 \\
\hline $\mathbf{2 4}$ & 6.4 & 7.1 \\
\hline $\mathbf{2}$ June & 6.9 & 7.7 \\
\hline $\mathbf{9}$ & 7.1 & 6.4 \\
\hline $\mathbf{1 6}$ & 4.3 & 3.2 \\
\hline $\mathbf{2 3}$ & 0.5 & 1.1 \\
\hline $\mathbf{3 0}$ & 0.0 & 0.3 \\
\hline $\mathbf{7}$ July & 0.0 & 0.0 \\
\hline Overall mean & 3.4 & 3.6 \\
\hline
\end{tabular}

\section{REFERENCES}

Abdel-Moneim, M.R.A., Fatma S. Ali and A.F. Turky (2012). Control of Tetranychus urticae Koch by extracts of three essential oils of chamomile, marjoram and Eucalyptus. Asian Pac. J. Biomed., 2 (1): 24-30.

Ali, Fatma S. (1998). Life tables of Phytoseiulus macropilis (Banks) (Gamasida: Phytoseeidae) at different temperatures. Exp. Appl. Acarology, 22: 335-342.

Ali, Fatma S., M.F. Hassan, E.M. El-Saidy and M.H. Mahgoub (2005). Influence of some sap sucking pests as preys on the biology and capacity of four predatory phytoseiid mite species. Egypt. J. Biol. Pest Cont., 15 (2): 99-102.

Antoniuos, G.F., K. Kamminga and J.C. Snyder (2014). Wild tomato leaf extracts for spider mite and cowpea aphid control. J. Environ. Sci. Health B., 49 (1): 527531.

El-Badry, L.A. and M.A. Zaher (1961). Life history of the predator mite Typhlodromus (Amblyseius) cucumeris Oudemans. Bull. Soc. Ent. Egypt., 45: 427-434.

El-Laithy, A.Y.M. (1992). Some aspects on the use of the predatory mite Phytoseiulus persimilis Athias-Henriot for the biological control of two spotted spider mite, Tetranychus urticae Koch in greenhouses in Egypt. J. Plant Dis. Prot., 99 (1): 93-100.

Fiedler, Z. (2012). Interaction between beneficial organisms in control of spider mite Tetranychus urticae (Koch). J. Plant Prot. Res., 52 (2): 226-229.

Geng, S., H. Shen, J. Zhang and H. Tu (2014). Bioactivity of garlic Straw extracts against the spider mites, Tetranychus urticae and T. viennensis. J. Agric. Urban Entomol., 30(1):38-48.

Hassan, M.F., Fatma S. Ali, A.M. Hussein and M.H. Mahgoub (2007). Control measures of Tetranychus urticae Koch on two cucumber cultivars in plastic houses. J. Egypt. Soc. Acarol., 1: 11-15.

Hassan, M.F., Fatma S. Ali, A.M. Hussein and M.H. Mahgoub (2008). Biological and chemical control of three plant piercing-sucking insect pests on cucumber in plastic houses. Egypt. J. Pest Control, 18 (1): 167-170.

Heikal, I.H. and M.H. Mowafi (1998). Biological control of Tetranychus urticae on bean plants by two introduced predators. Al-Azhar J. Agri. Res., 27: 185-196.

Heikal, I.H. and G.A. Ibrahim (2001). Release of Phytoseiulus macropilis (Banks) to control Tetranychus urticae Koch on strawberry in Ismailia 
Governorate, Egypt (Acari:Phytoseiidae, Tetranychidae). Egypt. J. Agri. Res., 79 (3): 893-906.

Heikal, I.H. and M.M. Fawzy (2003). A preliminary study on the biological control of Tetranychus urticae Koch on cucumber (Acari: Tetranychidae). Egypt. J. Agri. Res., 81 (1): 93-100.

Heikal, I.H., M.M. Fawzy, H.M. Ibrahim and G.A. Ibrahim (2000). Preliminary studies on the release of the predatory mite Phytoseiulus macropilis (Banks) on strawberry plants to control Tetranychus urticae Koch (Acari: Tetranychidae, Phytoseiidae). Egypt. J. Agric. Res., 78 (4): 1517-1523.

Henderson, C.E. and E.W. Tilton (1955). Tests with acaricides against the brown wheat mites. J. Econ. Entomol., 84: 157161.

Hossain, S., M.M. Haque and N. Naher (2006). Control of two spotted spider mite Tetranychus urticae Koch (Acari:Tetranychidae) by some selected chemicals. Univ. J. Zool., Rajshahi Univ., 25: 15-18.

Jepson, L.R., H.H. Keifer and E.W. Baker (1975). Mites injurious to economic plants. University of California Press, 612 pp.

Price, J.F. (1993). Chemical control of the two-spotted spider mite, Tetranychus urticae Koch (Acari:Tetranychidae) in strawberries. Proc. Fla. State Hort. Soc., 106: 168-170.

Khalequzzaman, M., M. Mondal, M.F. Haque and M.S. Karim (2007). Predatory efficacy of Phytoseiulus persimilis AthiasHenriot (Acari: Phytoseiidae) on the twospotted spider mite Tetranychus urticae Koch (Acari:Tetranychidae). J. Biol., Sci., 15: 127-132.

McMurtry, J.A. and B.A. Croft (1997). Life cycles of phytoseiid mites and their role in biological control. Ann. Rev. Entomol., 42: 291-321.

Muzemu, S., B.M. Mvumi, S.M. Nyirenda, G.W. Sileshi, P. Sola, L. Chikukura, J.F. Kamanula, S.R. Belmain and P.C.
Stevenson (2011). Pesticidal effects of indigenous plant extracts against rape aphids and tomato red spider mites. African Crop Sci. Conf. Proc., 10: 171 173.

Port, C.M. and N.E.A. Scopes (1981). Biological control of the predatory mites Phytoseiulus persimilis of red spider mite (Tetranychus urticae Koch) infesting strawberries grown in 'walk-in' plastic tunnels. PI. Path., 30: 95-99.

Pozzebon, A., C. Duso, P. Tirello and P.B Ortiz (2011). Toxicity of thiamethoxam to Tetranychus urticae Koch and Phytoseiulus persimilis through different routes of exposure. Pest Mang. Sci., 67 (3): 352-359.

Shah, D.R. and A. Shukla (2014). Chemical control of two-spotted spider mite, Tetranychus urticae infesting gerbera (Gerbera jamesonii L.) under polyhouse condition. Pest Manag. in Horticultural Ecosystems, 20 (2): 155-161.

Rajashekar, Y., K.V. Ravindra and N. Bakthavatsalam (2014). Leaves of Lantana camara Linn. (Verbenaceae) as a potential insecticide for the management of three species of stored grain insect pests. J. Food Sci. Technol., 51 (11): 3494-3499.

Strong, W.B. and B.A. Croft (1995). Inoculative release of phytoseiid mites (Acarina:Phytoseiidae) into the rapidly expanding canopy of hops for control of Tetranychus urticae (Acarina: Tetranychidae). Environ. Entomol., 24 (2): 446-453.

Watanabe, M.A., G.J. De-Morales, I.J.R. Gastaldo and G. Nicolella (1994). Biological control of two-spotted mite with predatory Phytoseiids (Acari:Tetranychidae:Phytoseiidae) on cucumber and strawberry. Scientia Agricola, 51 (1): 75-81.

Zaher, M.A. and K.K. Shehata (1971). Biological studies on the predatory mite, Typhlodromus pyri Scheuten with the effect of prey and non-prey substances (Acarina:Phytoseiidae). Z. Ang. Ent., 67: 389-394. 


\section{دور المواد الحيوية فى مكافحة أكاروس العنكبوت الاحمر المنطفل \\ على نباتات الطماطم \\ محمد حمادة أحمد محجوب \\ معهد بحوث وقاية النباتات - مركز البحوث الزراعية}

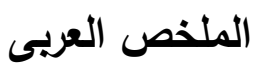

أجريت تجربة عملية بإحدى الصوب الزراعية البحثية بمعهد بحوث وقاية النباتات بالدقى للمقارنة بين ناثير

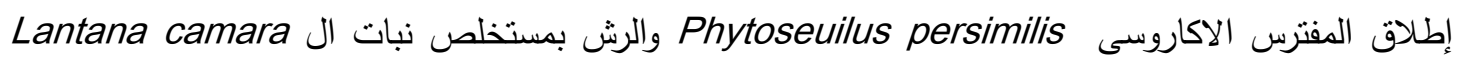
والرش بالمبيد الاكاروسى ( أورنس 5\% ) قى تقليل اعداد العنكبوت الاحمر Tetranychus urticae على نبات الطماطم صنف Alex 61 خلا الموسمين الزراعيين 2014 ، 2015 ـ 2015

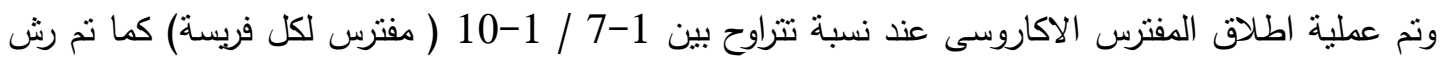

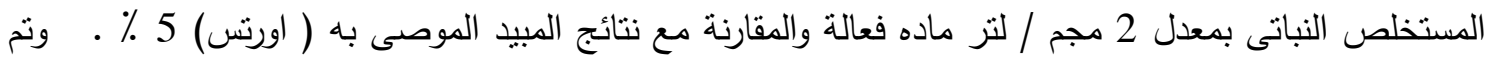

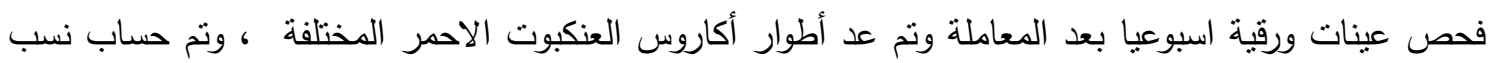

موت اطوار اكاروس العنكبوت الاحمر • واظهرت النتائج ان نسبة الموت من الافراد الكاملة خلاد الموسم 2014 كانت 89.7 ، 50.2 ، 76.7 ٪ لكل من المفترس الاكاروسى ومستخلص اللانتانا ومبيد الاورتس على التوالى ، بينما كانت 64.6 94.1 74.7 ، 81.7 ٪ على بيض العنكبوت الاحمر على التوالى . . واظهرت النتائج ان نسبة

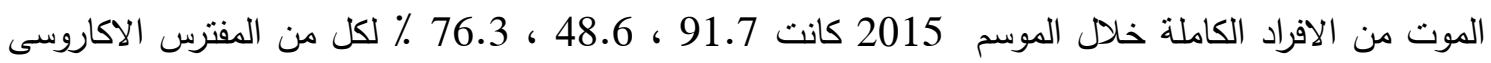
ومستخلص اللانتانا ومبيد الاورتس على التوالى ، بينما كانت 73.7 93، 72.5 ، 82.0 ٪ على بيض العنكبوت

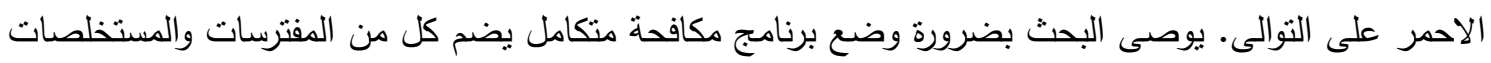

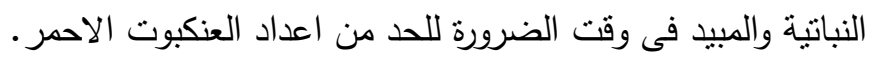

